\title{
Comentário a \\ “ELEMENTOS BÁSICOS DA TEORIA DA INDIVIDUAÇÃO DE Gilbert Simondon”: ProvocaÇóes Sobre a INDIVIdUAÇÁo EM SIMONDON
}

\author{
Fernando Maia Freire Ribeiro ${ }^{1}$
}

Referência do texto comentado: Cabral, Caio César. Elementos básicos da teoria da individuação de Gilbert Simondon. Trans/Form/Ação: revista de filosofia da Unesp, v. 44, n. 2, 2021, p. $63-82$.

A partir da composição entre as noçôes de campo (conforme desenvolvida pelo eletromagnetismo de Maxwell) e de informação (tomada especialmente dos trabalhos de Shannon e de Wiener), Simondon desenvolve uma teoria da individuação que se afasta dos quadros clássicos, tanto do substancialismo quanto do hilemorfismo. Duas teses que falhariam, justamente, por pressupor aquilo que deveria ser o objeto de explicação: o indivíduo constituído, e que, por isso, promoviam um processo de individuaçáo a reboque. Eis a novidade do projeto simondoniano: deslocar o interesse do processo, passar do indivíduo feito, que é somente uma fase no processo, para os regimes, para os modos de individuação.

A novidade vem sustentada por um novo modelo técnico: enquanto o hilemorfismo se baseava na fabricação de tijolos observada por quem,

\footnotetext{
${ }^{1}$ Docente na Universidade do Estado do Rio de Janeiro (UERJ), Rio de Janeiro, RJ -Brasil.

(D) https://orcid.org/0000-0003-1476-5736. E-mail: fmaiafr@gmail.com.
}

https://doi.org/10.1590/0101-3173.2021.v44n2.06.p83

\section{(i)}


literalmente, não colocou a mão na massa, a individuação com Simondon remete às válvulas tríodo. A diferença entre os dois modelos aponta para a necessidade de se situar em meio ao processo energético envolvido na produção do indivíduo, sem pressupor um princípio de individuação já contido, seja na forma, seja na matéria. Aqui se estabelece uma distinção cara a todos os que se deparam com a filosofia de Simondon, a diferença entre molde e modulação: moldar é modular de maneira definitiva, esse é o modelo da olaria vista de fora; modular é moldar de maneira contínua e perpetuamente variada, modelo da válvula com sua grade de comando que regula o fluxo de elétrons no interior da válvula, conforme alteraçôes se processam nos meios envolvidos. Fundamental se torna, então, pensar o indivíduo e o meio como efeitos de uma relaçáo. Isso leva a outra ideia forte: o novo estatuto da relaçáo, categoria que, de quase marginal no sistema aristotélico, ganha o estatuto de ser.

Tudo isso vem, a seu modo, muito bem apresentado nos Elementos básicos da teoria da individuação de Gilbert Simondon, de Caio César Cabral, mas, como nesse trabalho náo se especula sobre efeitos dessa filosofia, gostaríamos de apontar alguns elementos e levantar uma questão que incomoda alguns leitores de Simondon (entre eles, Bruno Latour e Isabelle Stengers): como se situar, hoje, em relação a esse pensamento?

Desde Gilles Deleuze, um dos primeiros a levar a sério e a usar de modo efetivo a filosofia de Simondon, alguma filtragem dos conceitos é exigida. Deleuze, por exemplo, adota o pré-individual, a metaestabilidade e usa sem parcimônia as singularidades, mas evita as conclusóes a que o sistema leva e se recusa, especialmente, em levar a transdução a toda parte. Assim como Deleuze, algumas leituras da própria obra de Simondon e de seus comentadores revelam algo incômodo: uma certa oscilação na dinâmica do processo, o qual, ao mesmo tempo que se volta para as relaçóes e para um mundo se fazendo, parece querer remontar a uma unidade perdida.

Não é o que ocorre na narrativa dos Modos de existência dos objetos técnicos, quando todos os diferentes modos surgem por defasagens de um modo único e se resolvem na unidade do sétimo e último modo (modo neutro, que, embora apareça apenas como tendência, levaria à superaçáo da defasagem entre ciência e ética)? Não por acaso, a referência de Simondon ao ser anterior à individuação é ao apeiron de Anaximandro, espécie de plano do possível que, numa tensão interna, se defasa, produzindo em si fases transitórias. Ao rejeitar as filosofias da individuação que só levavam em conta o indivíduo 
constituído, Simondon apontava, enfim, para um retorno à physys, a uma filosofia da natureza enquanto início e finalidade de todo processo.

Ao mesmo tempo que constatamos esse gosto pela unidade, percebemos uma tendência à generalização da experiência com o conceito de transdução retirado da gênese dos cristais e entendido conforme as teorias da informação. Esse é o modelo geral que será utilizado para a explicação dos diferentes modos de individuação (mantendo as características de cada operação, seja ela física, seja biológica, mental ou social, mas sempre tendo como referência o modelo de estruturação progressiva do cristal): a individuação do cristal que cresce pelas bordas, numa adesão, numa compatibilização do germe cristalino com meio amorfo metaestável, produzindo uma reverberaçấo comum do sistema. Emissor e receptor devem ser compatíveis, ou encontrar uma compatibilidade, para que haja informação e para que, daí, se efetuem indivíduo e meio.

$\mathrm{Na}$ sua polêmica contra a Gestalt e no deslocamento do sentido da "boa forma”, Simondon deixa claro o que vem a ser esse tipo de informação que ele distingue das formas clássicas. Ele pretende que tal forma deixe de ser a forma estável, para se tornar aquela capaz de atravessar, de animar, de estruturar domínios cada vez mais heterogêneos. Essa perspectiva que ronda toda a filosofia de Simondon se revela também no funcionamento do transindividual que é a verdadeira ferramenta universal de explicação dos agenciamentos coletivos: aqui as tensôes internas do sujeito, solidão e angústia, encontram numa individuação coletiva sua compatibilização.

Ao mesmo tempo autoconstituição do germe e desindividuação do meio a exigir novas individuaçóes, o transindividual é um bom exemplo de que as possibilidades criativas das relaçóes com suas capturas, hesitaçóes, torçóes, assimetrias... se tornam um caso de adesão, de compatibilização, receptores que aderem, ou não, à tensão de informação. A unidade recobrada da aventura dos modos se reflete aqui como unidade teórica que faz o caso cair na generalidade de um modelo que tudo explica. É por isso que Simondon incomoda, por um certo gosto pela resposta que distingue os que sabem dos que vivem na crença. Aqueles que sabem explicam tudo por meio de uma fórmula geral capaz de dar conta das experiências inusitadas, arriscadas, das construçóes criadas caso a caso, são os que partem da energia potencial e de uma natureza pré-individual dotada do poder de tudo explicar e de tudo unificar.

Essa junção de uma atmosfera unificadora e um desejo de estabelecer uma teoria geral, com a ideia de um processo de individuaçóes em ato 
sem pressuposição do indivíduo feito e sem princípio, aparece na forma de oscilaçóes que apontam ora para o se fazendo, ora para a generalização unificadora. Por isso, os comentadores de Simondon precisam se esforçar e anunciar todo o tempo que náo rebatem o devir no ser, produzindo, assim, curiosas elaboraçóes, sendo uma das mais reveladoras desse duplo movimento a "ontologia do devir".

Assim, se, por um lado, Simondon abre a porta para um pensamento relacional capaz de se lançar nas aventuras criativas dos encontros, por outro, parece fechar essa mesma porta, com um gosto pela unificação, pela generalização explicativa e pela compatibilização, as quais abortariam os desvios e - por que não dizer? - o realmente novo. Para herdar Simondon, náo seria preciso manter aberta a porta do pensamento relacional com tudo que ele pode oferecer e que levaria à ousadia especulativa de radicalizar o entre, o meso (não pensá-lo somente em termos de adesóes e compatibilizaçôes), no rumo das aventuras criativas que, afinal, já se realizam numa outra ecologia?

\section{REFERÊNCIA}

CABRAL, Caio César. Elementos básicos da teoria da individuação de Gilbert Simondon. Trans/Form/Açáo: revista de filosofia da Unesp, v. 44, n. 2, 2021, p. 63 - 82.

Recebido: 30/3/2020

Aceito: $03 / 4 / 2020$ 